\title{
Wound-healing evaluation of ointment from Stryphnodendron adstringens (barbatimão) in rat skin
}

\author{
Luzmarina Hernandes ${ }^{1, *}$, Luciene Marques da Silva Pereira ${ }^{1}$, \\ Fabiana Palazzo ${ }^{1}$, João Carlos Palazzo de Mello²
}

\author{
${ }^{1}$ Morphophysiological Sciences Department, University of Maringá, Paraná, Brazil, \\ ${ }^{2}$ Pharmacy Department, University of Maringá, Paraná, Brazil
}

\begin{abstract}
This study evaluated the cicatrizant effect of an ointment containing $1 \%$ of the ethyl-acetate fraction extracted from the stem bark of "barbatimão" (Stryphnodendron adstringens), in wounds made in the skin of rats, after 4, 7 and 10 days of treatment. Control wounds were treated with a base ointment without extract. The proliferation of keratinocytes in the area of reepithelialization was evaluated by counting the number of epithelial cells that were blocked in metaphase by vincristine sulfate. The length of the reepithelialized margin and the contraction of the wound were measured. Topical application of the "barbatimão" ointment stimulated proliferation of the keratinocytes, but had no effect on the length of the epithelium or on the contraction of the wounds.
\end{abstract}

Uniterms: Stryphnodendron adstringens/pharmacognosy. Stryphnodendron adstringens/ cicatrizant effect. "Barbatimão"/pharmacognosy. Wound/healing/experimental study. Reepithelialization.

\begin{abstract}
Neste estudo, avaliou-se a atividade cicatrizante de uma pomada contendo uma fração acetato de etila $1 \%$ obtida de cascas de "barbatimão" (Stryphnodendron adstringens) em feridas excisionais na pele de ratos após 4, 7 e 10 dias de tratamento. Feridas controle foram tratadas com pomada base, sem extrato. A proliferação dos queratinócitos na área reepitelizada foi avaliada através da contagem do número de queratinócitos bloqueados em metáfase, pelo sulfato de vincristina. O comprimento da margem reepitelizada e a contração das feridas foram mensurados. As feridas tratadas com barbatimão apresentaram um maior número de mitoses do que aquelas tratadas com a pomada base, em todos os tempos avaliados. A aplicação tópica da pomada de "barbatimão" estimulou a proliferação epitelial contudo não teve efeito sobre a migração dos queratinócitos ou sobre a contração das feridas.
\end{abstract}

Unitermos: Stryphnodendron adstringens/farmacognosia. Stryphnodendron adstringens/efeito cicatrizante. "Barbatimão"/farmacognosia. Feridas/cicatrização/estudo experimental. Reepitelização.

\section{INTRODUCTION}

In cutaneous lesions, tannins bind to the proteins of the injured tissues, precipitating them (Fernandez et al., 2002) and creating a protective layer (Neto et al., 1996). This layer isolates the wound site from the environment, reducing the permeability and exudation of the wound (Brown, Dattner, 1998; Bedi, Shenefelt, 2002) and promoting tissue repair. Tannins also exhibit vasoconstrictor and anti-inflammatory properties (Mota et al., 1985; Kapu et al., 2001) and stimulate the growth of epidermis,

\footnotetext{
"Correspondence: L. Hernandes. Morphophysiological Sciences Department, University of Maringá. Av. Colombo, 5790, 87020-900 - Maringá - PR, Brazil. E-mail: lhernandes@uem.br
}

aiding reepithelialization (Palermo et al., 2002; Lopes et $a l ., 2005)$. Reepithelialization involves the proliferation and migration of cells from the edges of the wound, and is regulated by mechanisms involving genes, growth factors, integrins, extracellular matrices (ECM) and metalloproteinases (MMPs) (Santoro, Gaudino, 2005).

Stryphnodendron Martius, Leguminosae, popularly known as "barbatimão", is a Brazilian savannah tree. Extracts of the stem bark from species of Stryphnodendron have several medically useful properties, such as antiinflammatory (Melo et al., 2007), antimicrobial (Lopes et al., 2005; Ishida et al., 2006), antiulcerogenic (Audi et al., 1999), trypanocidal (Holetz et al., 2005), antioxidant and cicatrizant (Lopes et al., 2005) properties, probably 
because of their high tannin content (about 20\%) (Audi et al., 2004). The content of tannins in Stryphnodendron adstringens was demonstrated by Mello et al. (1996a; 1996b, 1999), who isolated 23 compounds from these tannins. Recently, Lopes et al. (2008) reported five new compounds from stem bark of $S$. adstringens and S. polyphyllum. Popular uses such as a cicatrizant have been evaluated by previous studies, which have demonstrated a significant cicatrizant property of the bark extract from $S$. adstringens (Neto et al., 1996; Palermo et al., 2002).

The aim of the present study was to evaluate the cicatrizant activity of a semipurified fraction of the bark of $S$. adstringens, on the regeneration of the epidermis in wounds to the skin of rats.

\section{MATERIAL AND METHODS}

\section{Plant material and preparation of extracts}

The stem bark of $S$. adstringens (Mart.) Coville was collected in São Jerônimo da Serra, Paraná State, Brazil (S2343'7.8", W5045'23.5"; altitude $926 \mathrm{~m}$ ), in November 1999. The species was identified by Prof. Dr. Cássia Mônica Sakuragui (UEM). A voucher specimen was deposited at the Herbarium of the Biology Department of the Universidade Estadual de Maringá (UEM) under number HUEM 3800.

Air-dried stem bark was extracted with $\mathrm{Me}_{2} \mathrm{CO}-\mathrm{H}_{2} \mathrm{O}$ (7:3) (F1) according to Mello et al. (1999). The combined extracts were filtered and evaporated under reduced pressure, and lyophilized. This crude extract (50 g) was redissolved in $\mathrm{H}_{2} \mathrm{O}$ and extracted with ethyl acetate (EtOAc). After evaporation, the EtOAc fraction (F3; $7.8 \mathrm{~g}$ ) and the remaining $\mathrm{H}_{2} \mathrm{O}$ phase $(\mathrm{F} 2 ; 32 \mathrm{~g}$ ) produced dark-brown solids, and both fractions were lyophilized.

\section{Ointment preparation and animals}

Tests were done using the EtOAc fraction (F3) incorporated into an ointment base (Beeler base), with a final concentration of $1 \%$. Fifteen male Wistar ${ }^{\circledR}$ rats weighing from 180 to $200 \mathrm{~g}$ were used for the study. The animals were maintained in individual cages, in a 12-h light/dark cycle, temperature of $22{ }^{\circ} \mathrm{C}$, with a standard laboratory diet $\left(\mathrm{Nuvita}^{\circledR}\right)$ and water ad libitum. The protocol for these experiments was accepted and approved by the UEM Animal Ethics Committee (Protocol Number 040/2003).

\section{Cicatrization assay}

After manual depilation and asepsis, two round excisional wounds about $7 \mathrm{~mm}$ in diameter were made on the back of each animal, close to the cervical area, after demarcation with a stainless steel delimitor. After the wounds were washed and their longest transverse and longitudinal axes measured, the experimental wounds (on the right side) were treated daily with an ointment containing $1 \%$ of the F3 fraction. The control wounds (left side) were treated only with the ointment base without the extract (Lopes et al., 2005).

The rats were sacrificed after 4,7 or 10 days. Two hours before sacrifice, each rat was injected with $0.5 \mathrm{mg} /$ $\mathrm{kg}$ body weight of vincristine sulfate (Oncovin, Eli Lilly), a metaphase-arrest agent that blocks mitosis primarily by inhibiting the dynamics of spindle microtubules (Jordan et al., 1992). The wounds were measured again.

The rats were anesthetized by inhalation with ethyl ether, and the wounded skin was removed. The samples were spread on cards, fixed in Bouin's solution for 6 hours, and embedded in paraffin. Blocks were cut into $4 \mu \mathrm{m}$-thick sections. The slides were then stained with haematoxylin and eosin. The samples taken from the skin were used to evaluate cicatrization.

\section{Cell proliferation}

Cell proliferation in the epidermis was evaluated by counting the epithelial cells arrested in metaphase, in the basal and supra-basal layers on the reepithelialization surface. In both wounds of each animal, the number of blocked metaphases was counted in 100 microscope fields, with the aid of a $105 \mu \mathrm{m}$ ocular ruler fitted to an Olympus BX41 microscope, and a 40X objective. The results were expressed as number of metaphases $/ \mathrm{mm}$.

\section{Morphometry of the wounds}

The maximum length and width of each wound were measured with calipers on the day the wound was made and again on the day the animal was sacrificed; the wound area was calculated from these measurements. The degree of contraction of the wound was determined from the difference between the initial and final areas. The means of the differences between the experimental wounds and the controls were compared.

\section{Morphometric analysis of the reepithelialization surface}

Measurements of epithelium length were made in 10 sections/wound/animal from the reepithelialization surface, with the aid of a $1030 \mu \mathrm{m}$ ocular ruler fitted to an Olym- 
pus BX41 microscope, and a 10X objective. In wounds 4 and 7 days old, two margins of reepithelialization were measured, and the final measurement calculated as the sum of both. The results were expressed in micrometers.

\section{Statistical analysis}

The results were analyzed by the unpaired Student's $t$-test. The significance level was $\mathrm{P}<0.05$.

\section{RESULTS AND DISCUSSION}

The cicatrizant effect of an ointment containing 1\% of the ethyl-acetate fraction (F3) of barbatimão (S. adstringens) on wounds excised in the skin of rats was assessed. Topical application of the ointment exerted a trophic effect on the keratinocytes, stimulating a proliferative response of these cells along the margin of the reepithelialization. This response was detected after 4, 7 and 10 days of treatment (Figure 1). The mechanism by which $S$. adstringens stimulates cellular proliferation remains unknown, but is believed to be related to the tannin content of its bark (Lopes et al., 2005): the astringent property of tannin favors faster closure of lesions (Favaretto et al., 1985).

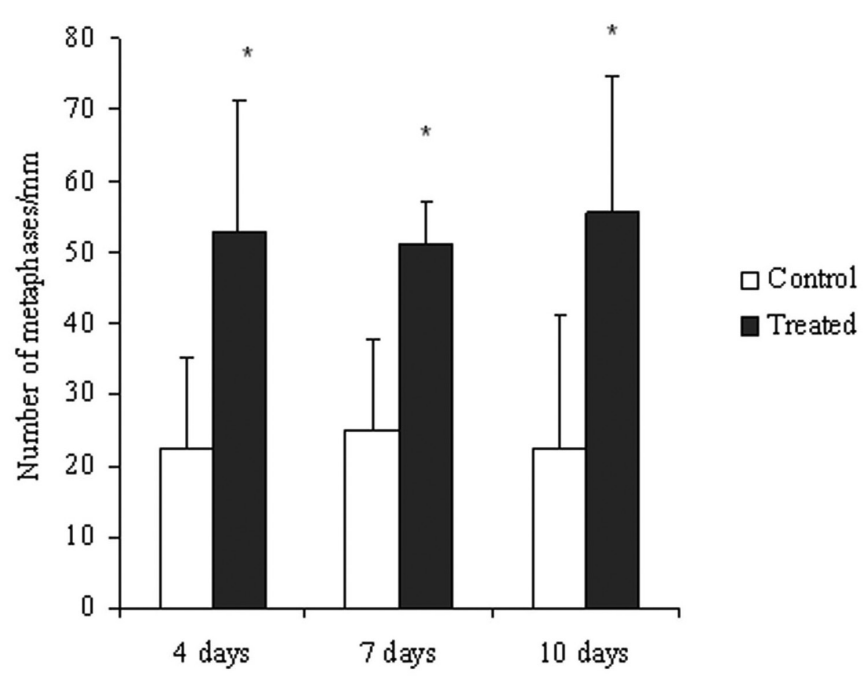

FIGURE 1 - Effect of treatment of cutaneous wounds after 4, 7 and 10 days with ointment containing $1 \%$ ethyl-acetate fraction from stem bark of $S$. adstringens on the number of metaphases $/ \mathrm{mm}$ in the newly formed epithelium. Mean \pm S.D. $(\mathrm{n}=5), * \mathrm{P}<0.05$ compared to the control.

Tannins are phenol compounds produced by the secondary metabolism of plants. They have an important astringent action, which increases the number of cross-links among collagen fibers in the collagen-rich matrix (tanning) (van Gulik, 1981; Haslam, 1998). In lesions caused by burns, tannins coagulate lipid-protein complexes and accelerate the formation of a flexible scab that covers the wound (Hupkens et al., 1995).

In this study, a flexible brown scab was observed after 4 days of treatment, and remained until the seventh day. On the tenth day, only a small cicatricial scar was observed.

Tannins also aid vasoconstriction, reducing vascular permeability and producing an anti-inflammatory action (Kapu et al., 2001; Mota et al., 1985). In addition, they have an antimicrobial effect (Schulz et al., 2002; Lopes et al., 2005).

Wounds treated with the ethyl-acetate fraction of two species of barbatimão were tested for proliferative activity of keratinocytes in the experimental wounds. Wounds treated with the $S$. obovatum fraction showed increases in epidermal proliferation only 4 days after treatment; whereas for $S$. polyphyllum, cell proliferation was observed after 4 and 7 days of treatment. These results suggest that the differences in the proliferative activity may be a function of the difference in the tannin content of the stem bark, which in S. polyphyllum is $12 \%$ and in S. obovatum is $19 \%$. The extracts of S. polyphyllum were more effective with respect to the biological activities tested, although the extracts had a lower tannin content. This is probably a result of differences between the substances from the two species: profisetinidins were found in S. polyphyllum, whereas prodelphinidins were identified in S. obovatum (Lopes et al., 2003; Sanches et al., 2005; Lopes et al., 2005; Lopes et al., 2008).

The total tannin content of $S$. adstringens $(19 \%)$ is higher than that measured for S. polyphyllum (12\%), as shown by Audi et al. (2004) and Lopes et al. (2005). Similar results were obtained by Santos et al. (2002), using different analytical techniques. These authors, however, showed that $S$. polyphyllum contains a larger amount of esterified gallic acid linkage with flavan-3-ols than does $S$. adstringens, which markedly increases free-radical scavenging (Hagerman et al., 1998; De Bruyne et al., 1999a and 1999b), anti-glucosyltransferase, anti-viral (De Bruyne et al., 1999a and 1999b), and anti-cancer activities (Dufresne, Farnworth, 2001). Nevertheless, the greater galloylation linkage with flavan-3-ols in $S$. polyphyllum was not found to be more efficacious in cicatrizant activity compared to $S$. adstringens, which in turn showed a greater mitogenic response.

In vitro experiments have demonstrated that polymeric proanthocyanidins extracted from Hamamelis virginiana stimulated the growth of keratinocytes, but did not stimulate their differentiation. Its action on cell growth depended on continuous application in the culture medium, for long periods of time (Deters et al., 2001). 
These results suggest that the proanthocyanidins present in the F3 fraction of $S$. adstringens may be responsible for the trophic effect on the epidermis observed in this study.

Grape-seed proanthocyanidins also stimulate the expression of VEGF (Vascular Endothelial Growth Factor) by keratinocytes in culture (Khanna et al., 2001). VEGF can induce the migration and proliferation of endothelial cells and increase vascular permeability (Inoue et al., 1998). These events are consistent with the capacity to promote angiogenesis, which has a central role in cicatrization.

Treatment with the ointment containing $1 \%$ of the F3 fraction from $S$. adstringens did not influence the migration of keratinocytes. No difference in the length of newly formed epithelium was found between the treated and control wounds (Figure 2).

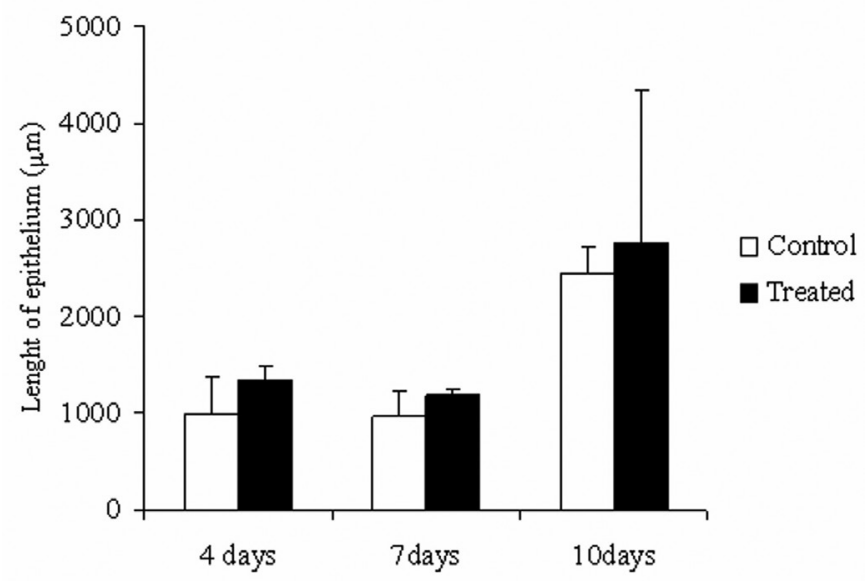

FIGURE 2 - Effect of treatment of cutaneous wounds with ointment containing $1 \%$ ethyl-acetate fraction from stem bark of $S$. adstringens on the length $(\mu \mathrm{m})$ of the newly formed epithelium. Mean \pm S.D. $(n=5) * \mathrm{P}<0.05$ compared to the control.

The phenomenon of migration is influenced by the nature of the surrounding extracellular matrix and the protein composition of the wound environment (Donaldson, Mahan, 1988; Bernstein et al., 1996). Therefore, the coagulant action of the proanthocyanidins present in the barbatimão ointment may interfere with migration of the keratinocytes.

The barbatimão ointment also did not influence wound contraction (Figure 3). This suggests that the spatial arrangement of the proanthocyanidins in the fraction studied may not have been capable of causing the astringent effect that is necessary for contraction of wounds.

Therefore, the active compounds that are present in the barbatimão extract incorporated into the ointment, at

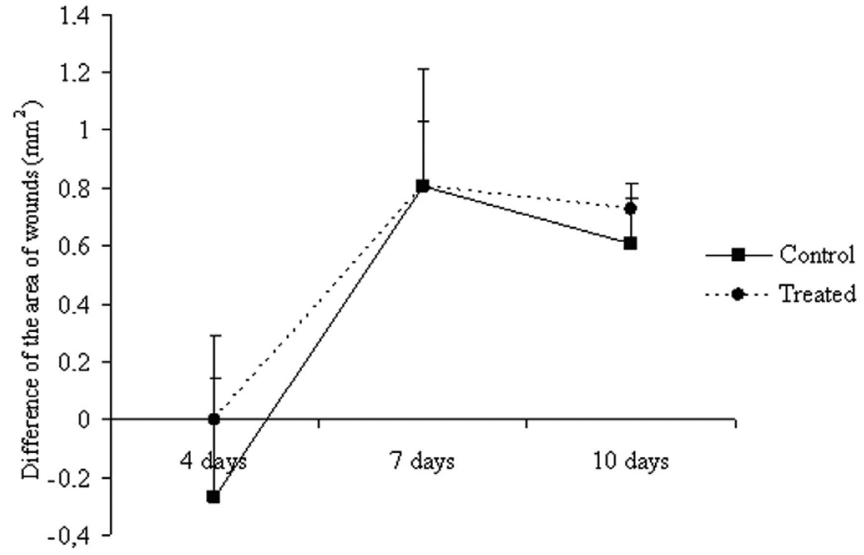

FIGURE 3 - Differences between the initial and final areas $\left(\mathrm{mm}^{2}\right)$ of cutaneous wounds treated with ointment containing 1\% ethyl-acetate fraction from stem bark of $S$. adstringens. Mean \pm S.D. $(\mathrm{n}=4),{ }^{*} \mathrm{P}<0.05$ compared to the control.

the dose tested, stimulated cell growth but not migration and did not influence contraction of the wounds. These results allow us to infer that the concentration and spatial arrangement of the proanthocyanidins present in the F3 fraction may be a preponderant factor in stimulating a response in the biological events that regulate the cicatricial process, being, at least in part, responsible for its medicinal use as a cicatrizant of cutaneous wounds.

\section{ACKNOWLEDGEMENTS}

We would like to thank CNPq, FINEP and Fundação Araucária for financial support. The technical assistance provided by Maria Euride Carlo Cancino, Admir Arantes and Cláudio Roberto Novello is gratefully acknowledged.

\section{REFERENCES}

AUDI, E.A.; TOLEDO, D.P.; PERES, P.G.; KIMURA, E.; PEREIRA, W.K.V.; DE MELLO, J.C.P.; NAKAMURA, C.; ALVES-DO-PRADO, W.; CUMAN, C.A.; BERSANIAMADO, C.A. Gastric antiulcerogenic effects of Stryphnodendron adstringens in rats. Phytother. Res., v.13, p.264-266, 1999.

AUDI, E.A.; TOLEDO, C.E.M.; SANTOS, F.S.; BELLANDA, P.R.; ALVES-DO-PRADO, W.; UEDA-NAKAMURA, T.; NAKAMURA, C.V.; SAKURAGUI, C.M.; BERSANIAMADO, C.A.; MELLO, J.C.P. Biological activity and quality control of extract and stem bark from Stryphnodendron adstringens. Acta Farm. Bonaerense, v.23, p.328-333, 2004. 
BERNSTEIN, E.F.; MAUVIEL, A.; MC GRATH, J.A.; BOLTEL, L.L.; FRANK, T.; UITTO, J. Wound healing. In: LASK, G.P.; MOY, R.L. (Eds.). Principles and techniques of cutaneous surgery. New York: McGraw-Hill, 1987. p.1-22.

BEDI, M.K.; SHENEFELT, P.D. Herbal therapy in dermatology. Arch. Dermatol., v.138, p.2332-2342, 2002.

BROWN, D.J.; DATTNER, A.M. Phytotherapeutic approaches to common dermatologic conditions. Arch. Dermatol., v.134, p.1401-1404, 1998.

DE BRUYNE, T.; PIETERS, L.; DEELSTRA, H.; VLIETINCK, A.J. Condensed vegetable tannins: Biodiversity in structure and biological activities. Biochem. Syst. Ecol. v.27, p.445459, 1999a.

DE BRUYNE, T.; PIETERS, L.; WITVROUW, M.; DE CLERCQ, E.; BERGHE, D.V.; VLIETINCK, A.J. Biological evaluation of proanthocyanidin dimers and related polyphenols. J. Nat. Prod., v.62, p.954-958, 1999 b.

DETERS, A.; DAUER, A.; SCHNETZ, E.; FARTASCH, M.; HENSEL, A. High molecular compounds (polysaccharides and proanthocyanidins) from Hamamelis virginiana bark: influence on human skin keratinocyte proliferation and differentiation and influence on irritated skin. Phytochemistry, v.58, p.949-958, 2001.

DONALDSON, D.J.; MAHAN, J.T. Keratinocyte migration and the extracellular matrix. J. Invest. Dermatol., v.90, p.623-828, 1988.

DUFRESNE, C.J.; FARNWORTH; E.R. A review of latest research findings on the health promotion properties of tea. J. Nut. Biochem. v.12, p.404-421, 2001.

FAVARETTO, A.L.V.; CONTRERA, M.G.D.; PETENUSCI, S.O.; SILVA-NETO, C.R.; LOPES, R.A.; SATAKE, T. Ação cicatrizante do extrato aquoso de casca de barbatimão Stryphnodendron obovatum Benth. em úlceras de contenção em ratos. Rev. Esc. Odontol. Alfenas, v.8, p.7-11, 1985.

FERNANDEZ, O.; CAPDEVILA, J.Z.; DALLA, G.; MELCHOR, G. Efficacy of Rhizophora mangle aqueous bark extract in the healing of open surgical wounds. Fitoterapia, v.73, p.564-568, 2002.
HAGERMAN, A.E.; RIEDL, K.M.; JONES, G.A.; SOVIK, K.N.; RITCHARD, N.T.; HARTZFELD, P.W.; RIECHEL, T.L. High molecular weight plant polyphenolics (tannins) as biological antioxidants. J. Agric. Food. Chem. v.46, p.1887-1892, 1998 .

HASLAM, E. Practical polyphenolics: from structure to molecular recognition and physiological action. Cambridge: Cambridge University Press, 1998. p.422.

HOLETZ, F.B.; UEDA-NAKAMURA, T.; DIAS FILHO, B.P.; MELLO, J.C.P.; MORGADO-DIAZ, J.A.; TOLEDO, C.E.M.; NAKAMURA, C.V. Biological effects of extracts obtained from Stryphnodendron adstringens on Herpetomonas samuelpessoai. Mem. Inst. Oswaldo Cruz, v.100, p.397-401, 2005.

HUPKENS, P.; BOXMA, H.; DOKTER, J. Tannic acid as topical agent in burns: historical considerations and implications for new developments. Burns, v. 21, p. 57-61, 1995.

INOUE, M.; ITOH, H.; UEDA, M.; NARUKO, T.; KOJIMA, A.; KOMATSU, R.; DOI, K.; OGAWA, Y.; TAMURA, N.; TAKAYA, K.; IGAKI, T.; YAMASHIDA, J.; CHUN, T.H.; MASATSUGU, K.; BECKER, A.E.; NAKAO, K. Vascular endothelial growth factor (VEGF) expression in human coronary atherosclerotic lesions: possible pathophysiological significance of VEGF in progression of atherosclerosis. Circulation, v.98, p.2108-2116, 1998.

ISHIDA, K.; MELLO, J.C.P.; CORTEZ, D.A.G.; DIAS FILHO, B.P.; UEDA-NAKAMURA, T.; NAKAMURA, C.V. Influence of tannins from Stryphnodendron adstringens on growth and virulence factors of Candida albicans. J. Antimicrob. Chemother., v.58, p.942-949, 2006.

JORDAN, M.A.; THROWER, D.; WILSON L. Effects of vinblastine, podophyllotoxin and nocodazole on mitotic spindles. Implications for the role of microtubule dynamics in mitosis. J. Cell Sci., v.102, p.401-416, 1992.

KAPU, S.D.; NGWAI, Y.B.; KAYODE, O.; AKAH, P.A.; WAMBEBE, C.; GAMANIEL, K. Anti-inflammatory, analgesic and anti-lymphocytic activities of the aqueous extract of Crinum giganteum. J. Ethnopharmacol., v.78, p.7-13, 2001.

KHANNA, S.; ROY, S.; BAGCHI, D.; BAGCHI, M.; SEN, C.K. Upregulation of oxidant-induced VEGF expression in cultured keratinocytes by a grape seed proanthocyanidin extract. Free Rad. Biol. Med., v.31, p.38-42, 2001. 
LOPES, G.C.; NAKAMURA, C.V.; DIAS FILHO, B.P.; MELLO, J.C.P. Estudos físico-químico, químico e biológico de cascas e extratos de Stryphnodendron polyphyllum Mart. (Leguminosae). Rev. Bras. Farmacogn. v.13, p.24-27, 2003.

LOPES, G.C.; SANCHES, A.C.C.; NAKAMURA, C.V.; DIAS FILHO, B.P.; HERNANDES, L.; MELLO, J.C.P. Influence of extracts of Stryphnodendron polyphyllum Mart. and Stryphnodendron obovatum Benth. on the cicatrisation of cutaneous wounds in rats. J. Ethnopharmacol., v.99, p.265-272, 2005.

LOPES, G.C.; MACHADO, F.A.V.; TOLEDO, C.E.M.; SAKURAGUI, C.M.; MELLO, J.C.P. Chemotaxonomic significance of 5-deoxyproanthocyanidins in Stryphnodendron species. Biochem. Syst. Ecol., v.36, p.925-931, 2008.

MELO, J.O.; ENDO, T.H.; BERSANI-AMADO, L.E.; SVIDZINSKI, A.E.; BARONI, S.; MELLO, J.C.P.; BERSANI-AMADO, C.A. Effect of Stryphnodendron adstringens (barbatimão) bark on animal models of nociception. Rev. Bras. Ciên. Farmac. v.43, p.465-469, 2007.

MELLO, J.C.P.; PETEREIT, F.; NAHRSTEDT, A. Flavan-3-ols and prodelphinidins from Stryphnodendron adstringens. Phytochemistry, v.41, p.807-813, 1996a.

MELLO, J.C.P.; PETEREIT, F.; NAHRSTEDT, A. Prorobinetidins from Stryphnodendron adstringens. Phytochemistry, v.42, p.857-862, 1996b.

MELLO, J.C.P.; PETEREIT, F.; NAHRSTEDT, A. A dimeric proanthocyanidin from Stryphnodendron adstringens. Phytochemistry, v.51, p.1105-1107, 1999.
MOTA, M.L.; THOMAS, G.; BARBOSA FILHO, J.M. Antiinflammatory actions of tannins isolated from the bark of Anacardium occidentale L. J. Ethnopharmacol. v.13, p.289-300, 1985.

NETO, J.J.; FRACASSO, J.F.; NEVES, M.C.L.C.; SANTOS, L.E.; BANUTH, V.L. Tratamento de úlcera varicosa e lesões de pele com Calendula officinalis e/ou com Stryphnodendron barbatiman (Vellozo) Martius. Rev. Ciênc. Farm. v.17, p.181-186, 1996.

PALERMO, D.; PEREIRA, L.C.M.S.; MELLO, J.C.P.; HERNANDES, L. Atividade cicatrizante do barbatimão [Stryphnodendron adstringens (Martius) Coville] em feridas cutâneas. Arq. Apadec., v.6, p.2, 2002.

SANCHES, A.C.C.; LOPES, G.C.; NAKAMURA, C.V.; DIAS FILHO, B.P.; MELLO, J.C.P. Antioxidant and antifungal activities of extracts and condensed tannins from Stryphnodendron obovatum Benth.. Rev. Bras. Ciênc. Farm., v.41, p.101-107, 2005.

SANTORO, M.M.; GAUDINO, G. Cellular and molecular facets of keratinocyte reepithelization during wound healing. Exp. Cell Res., v.304, p.274-286, 2005.

SANTOS, C.S.; COSTA, W.F.; RIBEIRO, J.P.; GUIMARÃES, D.O.; FERRI, P.H.; FERREIRA, H.D.; SERAPHIN, J.C. Tannin composition of barbatimão species. Fitoterapia, v.73, p.292-299, 2002.

SCHULZ, V.; HÄNSEL, R.; TYLER, V.E. Fitoterapia racional: um guia de fitoterapia para as ciências da saúde. 4.ed. São Paulo: Manole, 2002. 386 p.

VAN GULIK, T.M. Processed dermal sheep collagen as a biomaterial: an experimental study. Amsterdam, 1981. 61 p. [Doctoral thesis. University of Amsterdam].

Received for publication on $10^{\text {th }}$ March 2008 Accepted for publication on $24^{\text {th }}$ March 2010 